Gerrit Sonnenrein, Elmar Baumhögger, Andreas Elsner, A. Morbach, M. Neukötter, Andreas Paul, Jadran Vrabec

\title{
Improving the performance of household refrigerating appliances through the integration of phase change materials in the context of the new global refrigerator standard IEC
} 62552:2015

Journal article | Accepted manuscript (Postprint)

This version is available at https://doi.org/10.14279/depositonce-10924

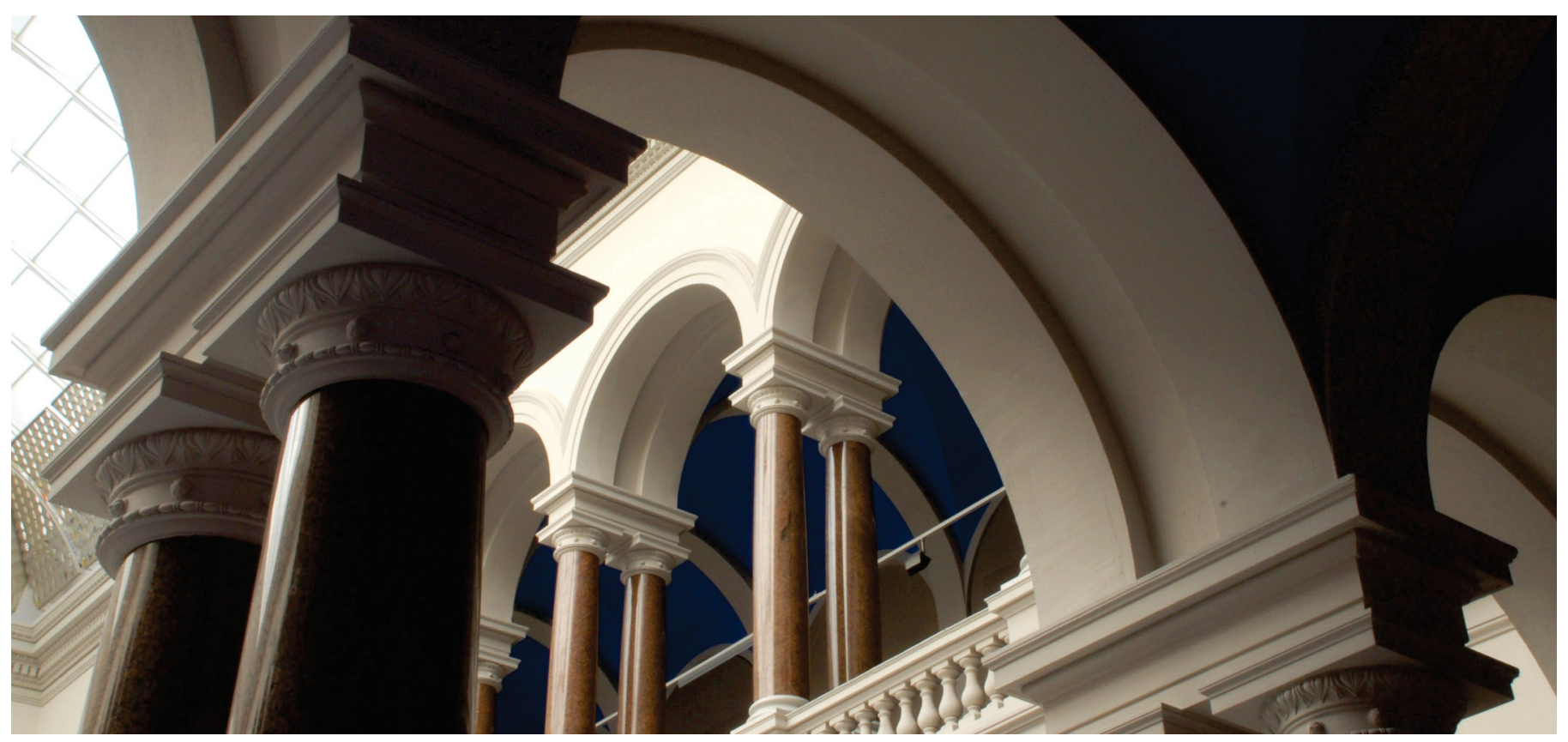

Sonnenrein, G., Baumhögger, E., Elsner, A., Morbach, A., Neukötter, M., Paul, A., \& Vrabec, J. (2020). Improving the performance of household refrigerating appliances through the integration of phase change materials in the context of the new global refrigerator standard IEC 62552:2015. International Journal of Refrigeration, 119, 448-456. https://doi.org/10.1016/j.ijrefrig.2020.07.025 
Accepted manuscript of: Sonnenrein, G. et al. (2020). Improving the performance of household refrigerating appliances through the integration of phase change materials in the context of the new global refrigerator standard IEC 62552:2015. International Journal of Refrigeration, 119, 448-456. https://doi.org/10.1016/j.jirefrig.2020.07.025

(C) 2020 This manuscript version is made available under the CC-BY-NC-ND 4.0 license https://creativecommons.org/licenses/by-nc-nd/4.0/

\title{
Improving the performance of household refrigerating appliances through the integration of phase change materials in the context of the new global refrigerator standard IEC 62552:2015
}

\author{
G. Sonnenrein ${ }^{\mathrm{a}}$, \\ E. Baumhöggera, \\ A. Elsnera, \\ A. Morbach ${ }^{\text {, }}$ \\ M. Neuköttera, \\ A. Paula, J. Vrabec ${ }^{c, 1}$ \\ a Thermodynamics and Energy Technology, University of Paderborn, \\ Warburger Str. 100, 33098 Paderborn, Germany \\ b Miele \& Cie. KG, Carl-Miele-Str. 29, 33332 Gütersloh, Germany \\ c Thermodynamics and Process Engineering, Technical University of Berlin, \\ Ernst-Reuter-Platz 1, 10587 Berlin, Germany
}

\section{Highlights}

- Copolymer-bound PCM are integrated in different refrigerating appliances.

- The impact on cooling capacity and temperature rise in the fresh-food compartments and power consumption is analyzed.

- Cooling capacity is increased by up to $33 \%$.

- Temperature rise time is increased by up to $145 \%$.

- The developed polymer-bound PCM are dimensionally stable and leak proof.

\section{Keywords}

Household refrigerator, Thermal storage, Phase change material, Cooling capacity, Temperature rise

\section{Abstract}

The influence of latent heat storage elements on the cooling performance and the temperature rise time of household refrigerating appliances is studied experimentally in the context of the "new global refrigerator standard" IEC 62552:2015 (IEC 62552:2015, 2015). In addition to the daily energy consumption, this international standardization introduced performance tests for cooling capacity and temperature rise time. While the cooling capacity has long been anchored in various test procedures of consumer organizations, the temperature rise time, which has only been tested on freezers so far, will be a decisive factor in the future. Moreover, the need for so-called "smart appliances" that may balance power consumption compensate the volatility of renewable energies and thus stabilize the power grid is increasing. Against this

\footnotetext{
${ }^{1}$ Corresponding author: vrabec@tu-berlin.de
} 
background, eight commercial household refrigerators and refrigerator-freezers are equipped with polymer-bound phase change materials (PCM) and their performance is determined under the new standard test conditions. The results show that the introduction of PCM increases the cooling capacity by up to $33 \%$ and also increases the temperature rise time by up to $145 \%$, without affecting power consumption, as compared to the unmodified refrigeration appliances.

\section{Nomenclature}

$h \quad$ specific enthalpy $\left(\mathrm{kJ} \mathrm{kg}^{-1}\right)$

$T$ temperature $\left({ }^{\circ} \mathrm{C}\right)$

$T M P_{i} \quad$ temperature measurement point

$T_{\text {ama }} \quad$ time averaged ambient temperature $\left({ }^{\circ} \mathrm{C}\right)$

$T_{i} \quad$ instantaneous refrigerator compartment temperature $\left({ }^{\circ} \mathrm{C}\right)$

$T_{m a}$ time averaged refrigerator compartment temperature $\left({ }^{\circ} \mathrm{C}\right)$

$T_{M i} \quad$ instantaneous M-package temperature $\left({ }^{\circ} \mathrm{C}\right)$

$T_{M, a} \quad$ arithmetic average of all instantaneous M-package temperatures $\left({ }^{\circ} \mathrm{C}\right)$

$T_{M, \max }$ instantaneous temperature of the warmest M-package $\left({ }^{\circ} \mathrm{C}\right)$

$\mathrm{Mi} \quad$ M-package number

\section{Introduction}

Although the power consumption of a single household refrigeration appliance appears to be low, the savings potential of the entire fleet is considerable due to the almost complete market penetration and typical continuous operation. In total, over 1.5 billion household refrigerators and freezers are in use worldwide, accounting for approximately $4 \%$ of global electricity consumption (Coloumb et al., 2015), annually causing 480 million tons of $\mathrm{CO}_{2}$ equivalent (Barthel and Götz, 2012). As a result test standards with sometimes striking energy labels were developed in many countries from as early as the 1990s. Meanwhile, energy efficiency has become a decisive purchase criterion for consumers (Faberi et al., 2007). However, these often very different standards and regulations require specific tests for the regional distribution of these products, which in turn entails considerable efforts in time and money. For this reason, e.g. Bansal (2003) called for the creation of a single, consolidated testing standard. The development of this so-called "global standard" already began in 2006 and led to the new IEC 62552:2015 "Household refrigerating appliances characteristics and test methods", which is currently being adapted into national standards in many countries and regions. In addition to the standardization of power consumption measurement, performance tests for cooling capacity and temperature 
rise time were now introduced. Table 1 provides an overview of the different test conditions for the daily energy consumption measurements of some of the most important international standards.

\section{Table 1 - Overview of different test conditions for energy consumption measurements.}

\begin{tabular}{lcccccc} 
Region & Europe & $\begin{array}{c}\text { Australia / } \\
\text { New Zealand }\end{array}$ & USA & USA & Japan & $\begin{array}{c}\text { Global } \\
\text { standard }\end{array}$ \\
\hline Standard & EN & AS/NZS & ANSI/AHAM & AHAM & JIS C 9801 & IEC \\
& $62552: 2013$ & $4474.1: 2007$ & HRF-1(2007) & HRF-1(2008) & (2006) & $62552: 2015$ \\
\hline
\end{tabular}

Energy consumption test

\begin{tabular}{|c|c|c|c|c|c|c|}
\hline $\begin{array}{l}\text { Ambient } \\
\text { temperature }\end{array}$ & $25^{\circ} \mathrm{C}$ & $32{ }^{\circ} \mathrm{C}$ & $32.2^{\circ} \mathrm{C}$ & $32.2^{\circ} \mathrm{C}$ & $\begin{array}{c}15^{\circ} \mathrm{C} \& \\
30^{\circ} \mathrm{C}\end{array}$ & $\begin{array}{c}16{ }^{\circ} \mathrm{C} \& \\
32{ }^{\circ} \mathrm{C}\end{array}$ \\
\hline $\begin{array}{l}\text { Fresh food } \\
\text { compartment } \\
\text { temperature } \\
\end{array}$ & $5^{\circ} \mathrm{C}$ & $3{ }^{\circ} \mathrm{C}$ & $3.3 / 7.22{ }^{\circ} \mathrm{C}$ & $3.9^{\circ} \mathrm{C}$ & $4^{\circ} \mathrm{C}$ & $4^{\circ} \mathrm{C}$ \\
\hline $\begin{array}{l}\text { Frozen food } \\
\text { compartment } \\
\text { temperature }\end{array}$ & $-18^{\circ} \mathrm{C}$ & $-15^{\circ} \mathrm{C}$ & $\begin{array}{c}-15 / \\
-17.8^{\circ} \mathrm{C}\end{array}$ & $-17.8^{\circ} \mathrm{C}$ & $-18^{\circ} \mathrm{C}$ & $-18^{\circ} \mathrm{C}$ \\
\hline $\begin{array}{l}\text { Loading of frozen } \\
\text { food } \\
\text { compartment }\end{array}$ & yes & no & $\begin{array}{l}\text { no (No-frost) } \\
\text { yes (static } \\
\text { cooling) }\end{array}$ & $\begin{array}{l}\text { no (No-frost) } \\
\text { yes (static } \\
\text { cooling) }\end{array}$ & $\begin{array}{l}\text { no (No-frost) } \\
\text { yes (static } \\
\text { cooling) }\end{array}$ & no \\
\hline $\begin{array}{l}\text { Door openings } \\
\text { and insertion of } \\
\text { warm load }\end{array}$ & no & no & no & no & $\begin{array}{c}\text { yes } \\
\text { (No-frost) }\end{array}$ & no \\
\hline
\end{tabular}

\begin{tabular}{|c|c|c|c|c|c|c|}
\hline $\begin{array}{l}\text { Ambient } \\
\text { temperature }\end{array}$ & $\begin{array}{c}10 / 16 \text { to } \\
32 / 38 / 43^{\circ} \mathrm{C}\end{array}$ & $10 / 32 / 43^{\circ} \mathrm{C}$ & $\begin{array}{c}12.8 / 21.1 / \\
32.2 / 43.3^{\circ} \mathrm{C}\end{array}$ & - & $15 / 30^{\circ} \mathrm{C}$ & $\begin{array}{c}10 / 16 \text { to } \\
32 / 38 / 43^{\circ} \mathrm{C}\end{array}$ \\
\hline $\begin{array}{l}\text { Fresh food } \\
\text { compartment } \\
\text { temperature }\end{array}$ & 0 to $4{ }^{\circ} \mathrm{C}$ & 0.5 to $6{ }^{\circ} \mathrm{C}$ & 1.1 to $5^{\circ} \mathrm{C}$ & - & 0 to $4{ }^{\circ} \mathrm{C}$ & 0 to $4{ }^{\circ} \mathrm{C}$ \\
\hline $\begin{array}{l}\text { Frozen food } \\
\text { compartment } \\
\text { temperature }\end{array}$ & $\leq-18^{\circ} \mathrm{C}$ & $\leq-15^{\circ} \mathrm{C}$ & $\begin{array}{c}\leq-15 / \\
-17.8{ }^{\circ} \mathrm{C}\end{array}$ & - & $\leq-18^{\circ} \mathrm{C}$ & $\leq-18^{\circ} \mathrm{C}$ \\
\hline $\begin{array}{l}\text { Loading of frozen } \\
\text { food } \\
\text { compartment }\end{array}$ & Yes & yes & yes & - & yes & yes \\
\hline reezing test & yes & no & no & no & yes & yes \\
\hline $\begin{array}{l}\text { emperature rise } \\
\text { est }\end{array}$ & yes & no & $\begin{array}{c}\text { yes } \\
\text { (freezers } \\
\text { only) }\end{array}$ & no & yes & yes \\
\hline ull-down test & no & yes & yes & no & yes & yes \\
\hline $\begin{array}{l}\text { utomatic ice- } \\
\text { naking test }\end{array}$ & yes & yes & yes & no & yes & yes \\
\hline
\end{tabular}

The positive influence of PCM, both on power consumption and temperature stability of household refrigeration appliances, has been known for a long time and has been the subject of scientific research in recent years, cf. Azzouz et. al (2008, 2009), Khan et. al. (2015), Oró et. al. (2012a, 2012b), Sonnenrein et. al. (2015a, 2015b) and 
references therein. PCM can absorb large amounts of heat at almost constant temperature and are thus particularly well suited for heat and cold storage. By implementing PCM, temperature fluctuations were reduced successfully in a variety of applications, e.g. transport boxes for sensitive goods or heat sinks for electronic devices. Mehling and Cabeza (2008) provide a general overview.

Already Onyejekwe (1989) attached a simple latent heat accumulator based on an eutectic $\mathrm{NaCl} / \mathrm{H} 2 \mathrm{O}$ mixture to the evaporator to increase the coefficient of performance (COP) of a refrigerator. Wang et al. (2007a,b,c) examined the influence of PCM at various locations in the cooling system and were able to raise their prototype's efficiency by 6-8 \%. Besides an increase of energy efficiency by 3-4 \% through a $1{ }^{\circ} \mathrm{C}$ increase of evaporator temperature, Cheralathan et al. (2007) were able to prove the potential of load shifting into cost-effective power night-rates of an industrial cooling device. A direct connection of different PCM-layers to the evaporator of a household refrigerator allowed Azzouz et al. $(2008,2009)$ to achieve a 10 to $15 \%$ increase of the COP through a higher evaporator temperature and simultaneously a considerable reduction of the on/off switch control frequency. Through PCM in contact with the refrigerator compartment evaporator of a domestic refrigerator/freezer appliance, Visek et al. (2014) showed an improvement of about $6 \%$ in terms of energy consumption during the refrigeration cycle.

In a preceeding study Sonnenrein et al. (2015) were able to reduce the power consumption by up to $12 \%$ through the integration of polymer-bound PCM into foamed as well as roll-bond evaporators. Yusuffoglu et al. (2015) achieved similar energy savings of about $10 \%$ in their studies on the integration of different PCM in foamed evaporators. Niyai et al. (2017) located PCM in a roll-bond evaporator of a domestic refrigerator and were able to reduce its compressor running time significantly. CofréToledo et al. (2018) studied the integration of two eutectic PCM and could also show an improved COP through an increase of the evaporator temperature, but the temperature of the refrigerator compartments was affected negatively. Investigations of Berdja et al. (2019) showed similar results. Maiorino et al. (2019) integrated water as a PCM in contact with the evaporator of a household refrigerator and showed a reduced switching frequency and lower temperature fluctuations in the refrigerator compartment. Ben-Abdallah et al. (2019) came to similar conclusions by integrating PCM into the evaporator of an open display cabinet. Although the most commonly studied PCM configuration is the integration into the evaporator, another possibility is the integration into the condenser. Cheng et al. (2011) were able to reduce the power consumption of a refrigerator/freezer combination by up to $12 \%$ through the integration of a paraffin-polyethylene compound on the integrated, i.e. foamed, condenser. In another investigation Sonnenrein et al. (2015) studied different options of sensible and latent heat storage elements integrated into standard wire-and-tube condensers and 
were able to reduce the power consumption by about $10 \%$ with a newly developed PCM polymer compound.

The third possibility is to integrate PCM inside the freezer or refrigerator to reduce temperature fluctuations or to slow down the temperature rise, e.g. in case of a power failure. Gin et al. (2010a, b) studied the temperature rise in a household freezer with integrated PCM panels during power loss, defrosting cycles as well as door openings and found an improved storage quality and a significantly slower temperature increase inside the freezer. Oró et al. (2012a) found consistent results for commercial freezers and also observed a significantly slower temperature rise in case of a refrigeration system failure (Oró et al., 2012b). Liu et al. (2017) placed a $\mathrm{NaCl} / \mathrm{H}_{2} \mathrm{O}$ mixture in the freezer and water as a PCM in the air duct of the fresh food chamber of an air-cooled frost-free refrigerator and found a decreased temperature rise in the fresh food and freezing compartments, but noticed an increase of power consumption depending on the operating mode. More studies about the application of PCM in refrigerators/freezers can be found in the reviews of Mastani Joybari et al. (2015) or Bista et al. (2018).

Together, these studies provide a good insight into the general advantages of PCM in refrigerators and freezers, such as the positive influence on COP, temperature fluctuations and on/off ratio. However, none examined the effects on the new standardized functional test procedures introduced internationally by the IEC 62552:2015. With this standard, cooling capacity and temperature rise time can now be quantified in the same way as the energy consumption and will thus play a comparable role in the future. Therefore, this paper studies the effect of a polymerbound PCM on (1) the cooling capacity and (2) the energy consumption according the IEC 62552:2015 of eight commercially available household refrigerators. Moreover, the effects on the (3) temperature rise time in the refrigerator compartment were determined. For this purpose, a test procedure was developed that is analogous to the IEC test for freezer in order to examine the refrigerators' suitability as future smart appliances.

\section{Test setup}

\subsection{Methodology}

The tests in this study were performed according to IEC 62552:2015 (IEC 62552:2015, 2015). The cooling capacity test determines the time required to cool a specific load (4.5 kg per $100 \mathrm{I}$ volume) from $25^{\circ} \mathrm{C}$ down to $10^{\circ} \mathrm{C}$; details can be found in Part 2 of the IEC standard. The original temperature rise test in the IEC standard determines the time interval for the temperature of a specific load to increase by a certain amount. 
In the case of a three- or four-star freezer compartment, this would be from $-18^{\circ} \mathrm{C}$ to $-9{ }^{\circ} \mathrm{C}$, once the operation of the refrigeration system has been interrupted, details can be found in Part 2 of the IEC-standard. Analogously, in this study the time interval was determined during which the temperature of a specific load in the refrigerator compartment rises from $8{ }^{\circ} \mathrm{C}$ to $11^{\circ} \mathrm{C}$. Following Part 3 of the IEC standard, all power consumption tests were also performed at an ambient temperature of $25^{\circ} \mathrm{C}$. Although the standard mentions energy consumption tests at 16 and $32{ }^{\circ} \mathrm{C}$ ambient temperature and an interpolation of the measurements results to $25^{\circ} \mathrm{C}$, the method can in principle be applied at any other ambient temperature.

\subsection{Measurement of temperatures and power consumption}

The test setup and all executed measurement procedures were in accordance with the IEC standard mentioned above. Fig. 1 schematically shows the standard temperature measurement positions $T M P_{1}, T M P_{2}$ and $T M P_{3}$ as well as the filling and distribution of test packages and M-packages (M1 to M6) in a fresh-food compartment.
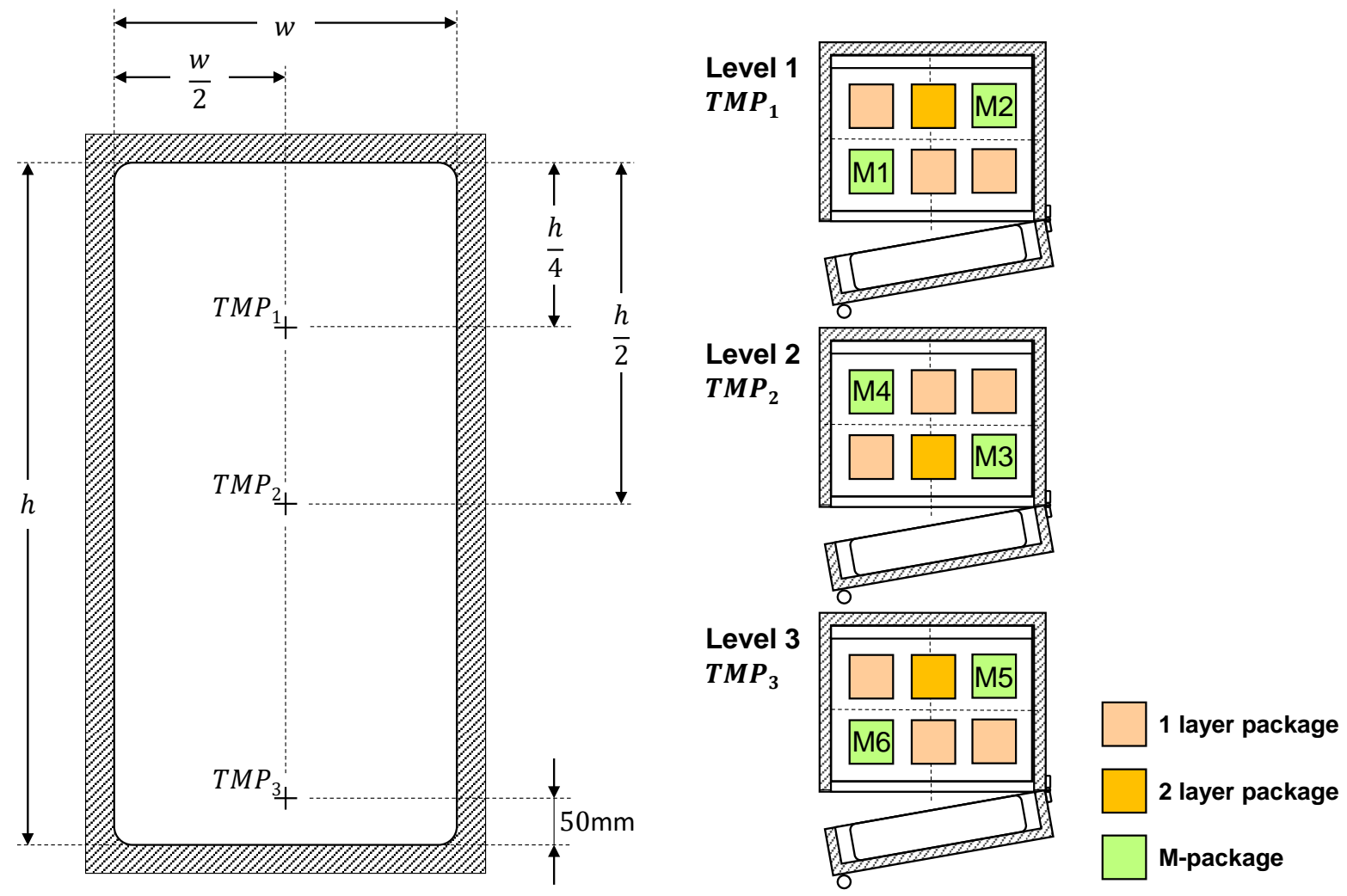

Fig. 1 Standard temperature measurement positions $T M P_{1}, T M P_{2}$ and $T M P_{3}$ (left) and the filling and distribution of test packages and M-packages in a fresh-food compartment (right). 
Temperature sampling was carried out by thermocouple differential measurements, each measuring point with a reference junction in an ice water bath. The utilized acquisition interface OMB-DAQ 55/56 (Omega Technologies) was combined with a pre-amplifier LTC1050 (Linear Technologies), which limits the offset conditioned by zero-point drift to $\pm 0.025 \mathrm{~K}$. The typical error of thermo-elements of $\pm 1 \% \times \Delta T$ in other work was reduced to $\pm 0.5 \% \times \Delta T$ by batch consistency and polynomial calibration. For determining the power consumption under standard conditions (average temperature of the fresh-food compartment $T_{m a}=4{ }^{\circ} \mathrm{C}$, ambient temperature $T_{\text {ama }}=25{ }^{\circ} \mathrm{C}$ and humidity $50 \%$ ), energy meters type EZI 1 (Zimmer Electronic Systems) with 25 pulses $/$ Wh were used, leading to a relative measurement error of $<1 \%$. Table 2 summarizes the measured quantities and their associated uncertainties.

\section{Table 2 - Measured properties and their uncertainties.}

\begin{tabular}{lcc} 
Measured quantity & Measuring device & Uncertainty \\
Temperature & Thermocouples & $\pm 0.1 \mathrm{~K}$ \\
Power & Energy meters & $\pm 0.05 \mathrm{~W}$ \\
Time & Personal computer & \pm 0.1 s/day \\
\hline
\end{tabular}

\subsection{Refrigerating appliances}

A total of eight commercially available refrigerators and refrigerator-freezers with volume capacities of the fresh food compartment between $158 \mathrm{I}$ and $320 \mathrm{I}$ were analyzed. Power consumption, cooling capacity and temperature rise tests were first performed with the appliances in their original state and subsequently with PCM. Table 3 summarizes the essential technical data of the examined appliances. Fig. 2 shows the setup of a fresh-food compartment equipped with PCM and M-Packages. 


\section{Table 3 - Technical data of the examined refrigerating appliances.}

\begin{tabular}{|c|c|c|c|c|c|c|c|c|}
\hline Test device & R1 & R2 & R3 & R4 & C1 & C2 & C3 & C4 \\
\hline $\begin{array}{l}\text { Combined } \\
\text { refrigerator- } \\
\text { freezer }\end{array}$ & no & no & no & no & yes & yes & yes & yes \\
\hline $\begin{array}{l}\text { Refrigerator } \\
\text { model }\end{array}$ & K9252i-1 & $\begin{array}{l}\mathrm{K} 12020 \\
\mathrm{~S}-1\end{array}$ & $\begin{array}{l}\text { KRIE } \\
2183\end{array}$ & $\begin{array}{l}\text { K37272 } \\
\text { iD }\end{array}$ & $\begin{array}{l}\text { CUPesf } \\
3503\end{array}$ & $\begin{array}{c}\text { KD12622 } \\
\text { S edt/cs }\end{array}$ & $\begin{array}{l}\text { KG39 } \\
\text { EAI40 }\end{array}$ & $\begin{array}{l}\text { BCD- } \\
\text { 185TNG }\end{array}$ \\
\hline $\begin{array}{l}\text { Manu- } \\
\text { facturer }\end{array}$ & Miele & Miele & $\begin{array}{c}\text { Bau- } \\
\text { knecht }\end{array}$ & Miele & Liebherr & Miele & Siemens & Haier \\
\hline $\begin{array}{l}\text { Dimensions } \\
(\mathrm{HxBxT}) \\
{[\mathrm{mm}]}\end{array}$ & $\begin{array}{c}872 x \\
540 x \\
550 \\
\end{array}$ & $\begin{array}{c}850 x \\
628 x \\
601 \\
\end{array}$ & $\begin{array}{c}1770 x \\
535 x \\
540 \\
\end{array}$ & $\begin{array}{c}1772 x \\
560 x \\
550 \\
\end{array}$ & $\begin{array}{c}1817 x \\
631 x \\
600 \\
\end{array}$ & $\begin{array}{c}1623 x \\
637 x \\
600 \\
\end{array}$ & $\begin{array}{c}2010 x \\
650 x \\
600 \\
\end{array}$ & $\begin{array}{c}1900 x \\
700 x \\
680 \\
\end{array}$ \\
\hline $\begin{array}{l}\text { Fridge } \\
\text { storage } \\
\text { volume [l] }\end{array}$ & 158 & 167 & 320 & 216 & 232 & 199 & 247 & 185 \\
\hline $\begin{array}{l}\text { Total storage } \\
\text { volume [l] }\end{array}$ & 158 & 167 & 320 & 216 & 323 & 253 & 339 & 243 \\
\hline Refrigerant & $\begin{array}{r}35 \mathrm{~g} \\
\mathrm{R} 600 \mathrm{a} \\
\end{array}$ & $\begin{array}{r}22 \mathrm{~g} \\
\mathrm{R} 600 \mathrm{a} \\
\end{array}$ & $\begin{array}{r}55 \mathrm{~g} \\
\mathrm{R} 600 \mathrm{a} \\
\end{array}$ & $\begin{array}{r}60 \mathrm{~g} \\
\mathrm{R} 600 \mathrm{a} \\
\end{array}$ & $\begin{array}{r}90 \mathrm{~g} \\
\mathrm{R} 600 \mathrm{a} \\
\end{array}$ & $\begin{array}{r}48 \mathrm{~g} \\
\mathrm{R} 600 \mathrm{a} \\
\end{array}$ & $\begin{array}{r}78 \mathrm{~g} \\
\mathrm{R} 600 \mathrm{a} \\
\end{array}$ & $\begin{array}{r}42 \mathrm{~g} \\
\mathrm{R} 600 \mathrm{a} \\
\end{array}$ \\
\hline Energy label & A++ & $A+$ & $A++$ & $A++$ & $\mathrm{A}++$ & A++ & $\mathrm{A}+++$ & $\mathrm{A}++$ \\
\hline
\end{tabular}




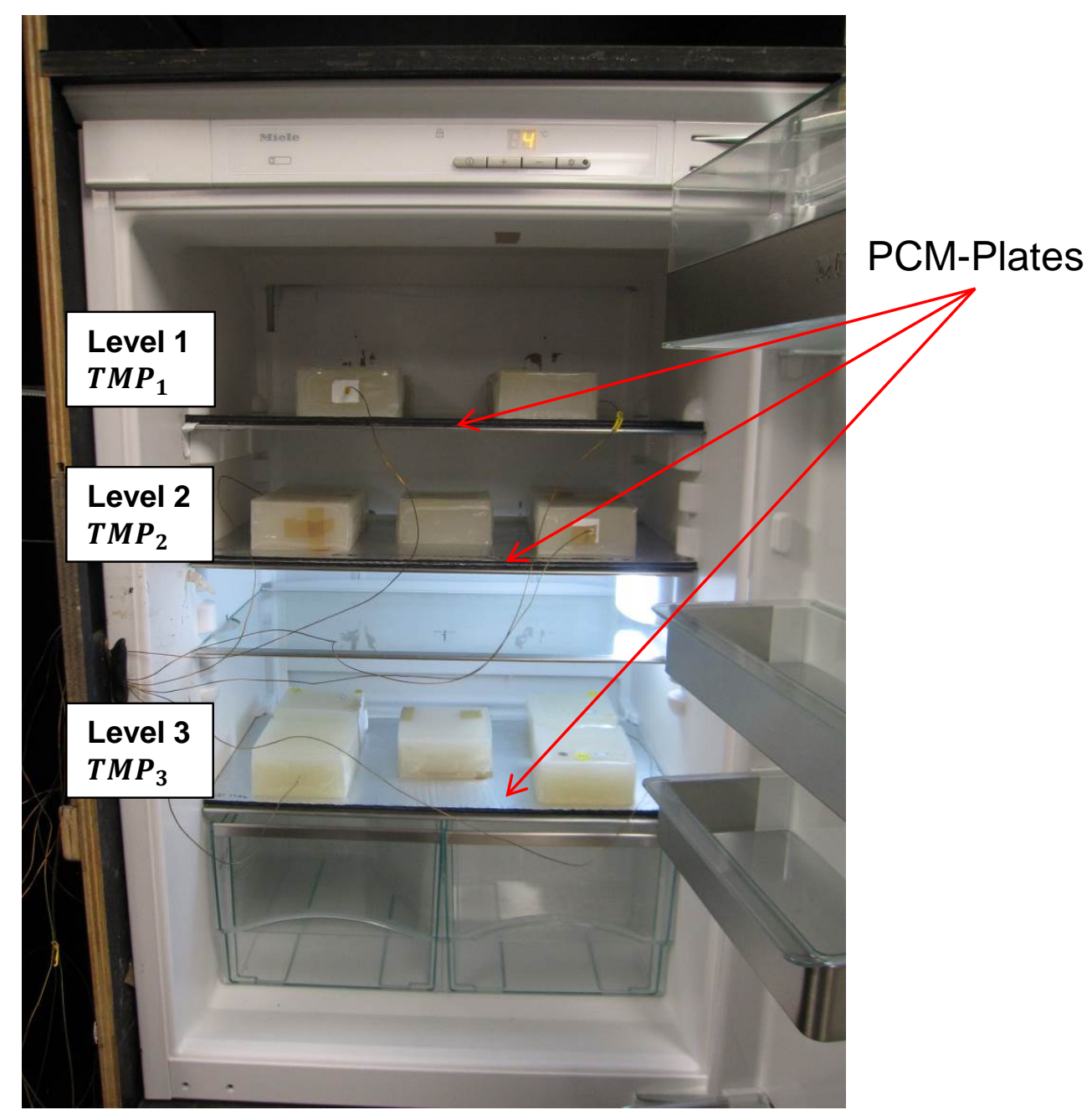

Fig. 2 Fresh-food compartment of a tested appliance equipped with PCM and M-packages.

\section{$2.4 \quad$ Heat storage materials}

High-capacitive, dimensionally stable latent heat storage elements based on polymerbound organic paraffin derivatives were developed in this study. In contrast to prior approaches, this compound material is dimensionally stable and in its "liquid" state it is secure against leakage and exudation. Therefore, an elaborate encapsulation is not necessary and the PCM compound was processed into foil-laminated sheets and integrated on top of shelves of the refrigerating appliances, in order to examine their influence on performance and power consumption. Depending on the size of the freshfood compartment and the number of shelves, between 1.79 and $2.96 \mathrm{~kg}$ of PCM were placed in the refrigerating appliances, corresponding to specific PCM densities of 0.72 to $1.41 \mathrm{~kg}$ per 100 I volume.

Fig. 3 shows the temperature dependence of the specific enthalpy $h$ of the compound developed for the integration in fresh-food compartments of refrigerating appliances. Measurements were done with Differential Scanning Calorimetry (DSC, SETARAM 
TG-DSC 111) and also with a heat flow three-layer calorimeter (W\&A, WOTKA), developed specifically for analyzing PCM. The latter allows for a considerably larger sample quantity than commercial DSC devices and therefore yields the phase change temperature more precisely. The specific enthalpy $h$ of the dimensionally stable polymer compound in the temperature range of from $0{ }^{\circ} \mathrm{C}$ to $15^{\circ} \mathrm{C}$ is about $150 \mathrm{~kJ} / \mathrm{kg}$ and the phase change temperature is around $9^{\circ} \mathrm{C}$.

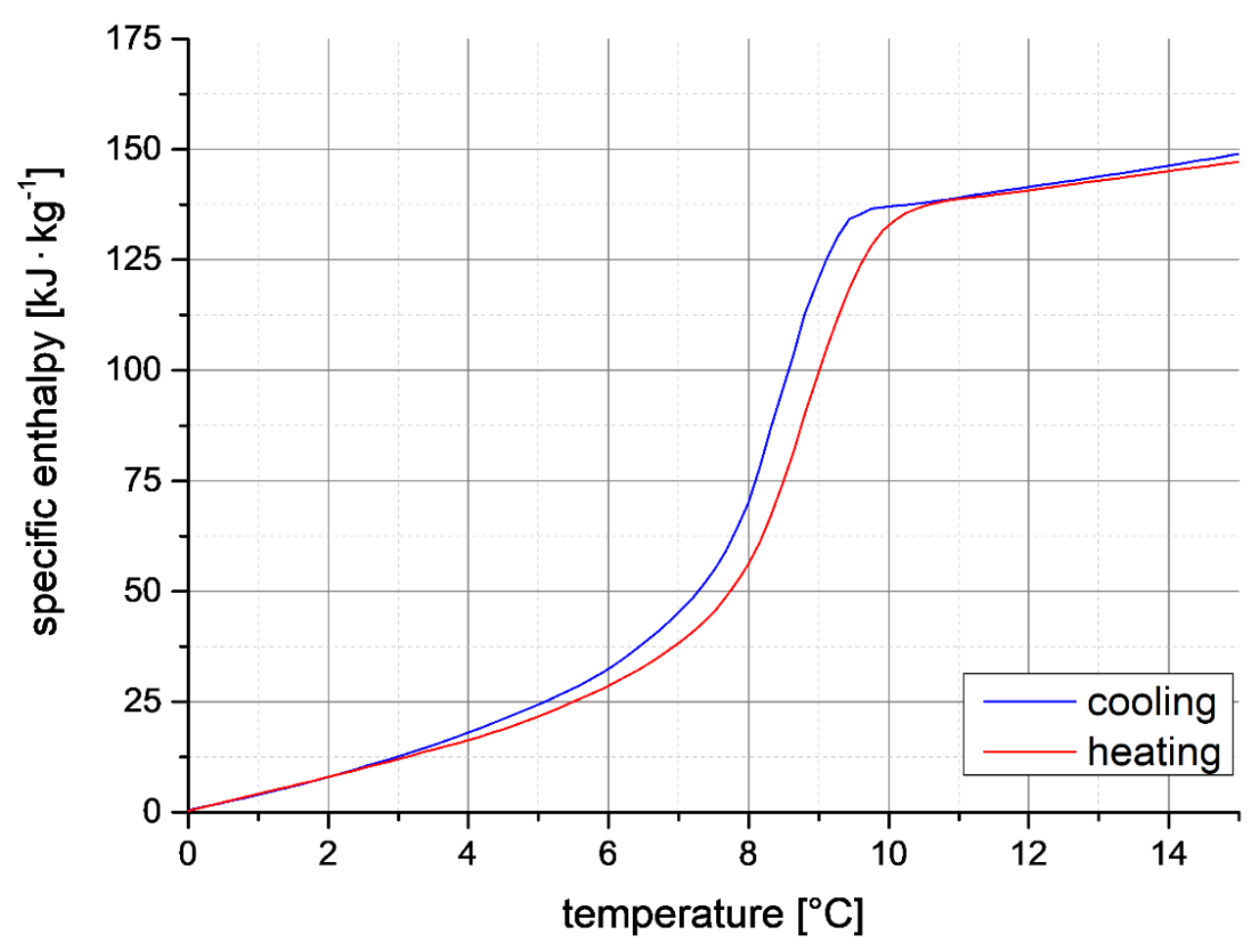

Fig. 3 Specific enthalpy as a function of temperature of the developed polymer compound.

Fig. 3 also shows a significant advantage of the present polymer compound compared to the salt-water or glycol solutions often used in other studies. The subcooling that is necessary for initiating solidification of these liquids, thus the difference between melting and freezing temperature, is typically between 5 and $15 \mathrm{~K}$, whereas the present polymer compound does not undergo significant subcooling. This is crucial for the use in the fresh food compartment, where only very small temperature differences are available for solidification and melting of the PCM. A further advantage of the present polymer compound is its transparency (or milky transparency), which also enables simple integration into the (e.g. double-walled) shelves in later practice, cf. Fig. 4. 


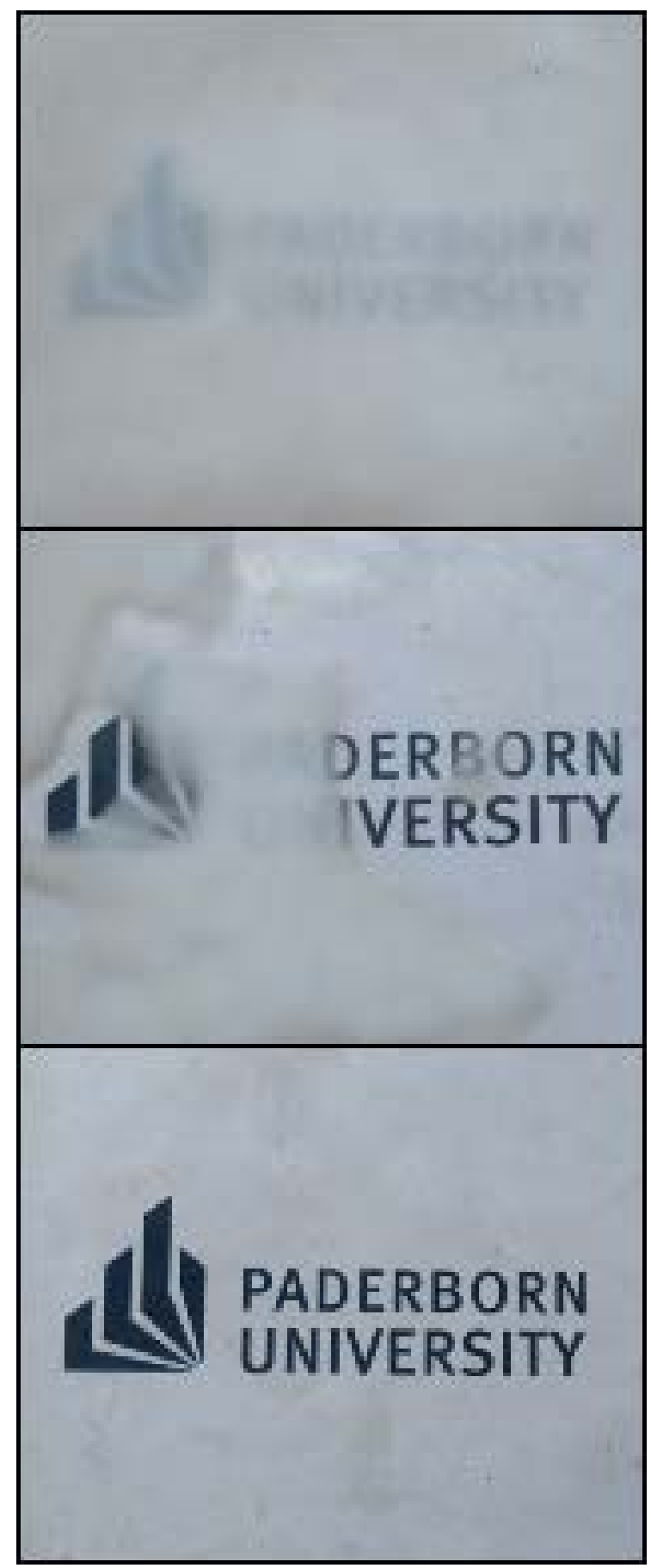

Fig. 4 Transparency of the present polymer compound from solid (up) to liquid (down).

\section{Results and discussion}

Experimental tests with eight commercially available household refrigerators and refrigerator-freezers, cf. Table 3, equipped with PCM polymer compound were carried out to investigate the effect on cooling capacity, temperature rise and daily energy consumption following the global standard IEC 62552:2015 (IEC 62552:2015, 2015). 


\subsection{Cooling capacity}

The cooling capacity test according to IEC 62552:2015 (IEC 62552:2015, 2015) determines the time required to cool a specific load (4.5 kg per 100 I volume) from $25^{\circ} \mathrm{C}$ down to $10^{\circ} \mathrm{C}$. For this purpose, the refrigerating appliances were each loaded with $4.5 \mathrm{~kg}$ per $100 \mathrm{I}$ (fresh-food compartment) volume with defined test- and Mpackages (IEC 62552:2015, Part 1, Annex C) according to a defined filling plan (IEC 62552:2015, Part 2, Chapter 7), cf. Fig. 1. Loading started when stable operating conditions with a mean temperature $T_{m a}=+4{ }^{\circ} \mathrm{C} \pm 0,5 \mathrm{~K}$ have been attained. In order to achieve comparable and reproducible results, loading always took place exactly at the start of a compressor cycle. And as defined in the standard, if the appliance had a "quick cooling" function, this was activated at the moment when the load was inserted. Fig. 5 shows an exemplary temperature curve of such a cooling capacity test, where the cooling time was measured by determining the time between loading and when the arithmetic mean of the temperatures of all M-packages $\left(T_{M, a}\right)$ has reached $10^{\circ} \mathrm{C}$.

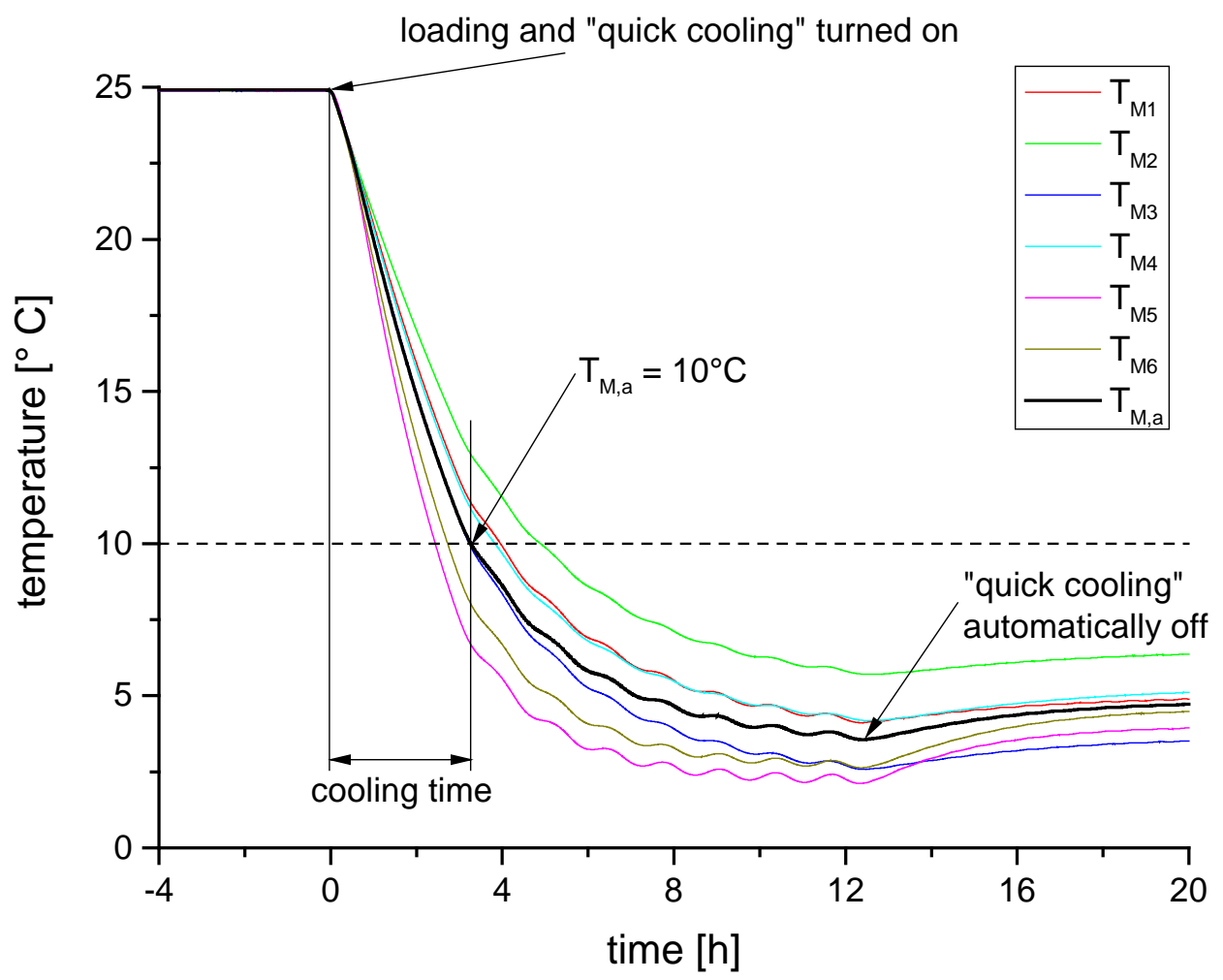

Fig. 5 Temperatures of the M-packages during the cooling capacity test according to IEC 62552:2015.

The influence of the latent heat storage elements integrated into the fresh-food compartment on the cooling time is exemplarily shown in Fig. 6. The cooling time of 
the refrigerator-freezer C1 equipped with PCM was reduced by $33 \%$ from 5.9 to $3.9 \mathrm{~h}$. Fig. 7 summarizes the results of all cooling capacity measurements. The cooling time could be significantly shortened by the PCM for all refrigerating appliances, i.e. between 0.55 to $2.00 \mathrm{~h}$ in absolute terms and between 16 to $33 \%$ in relative terms.

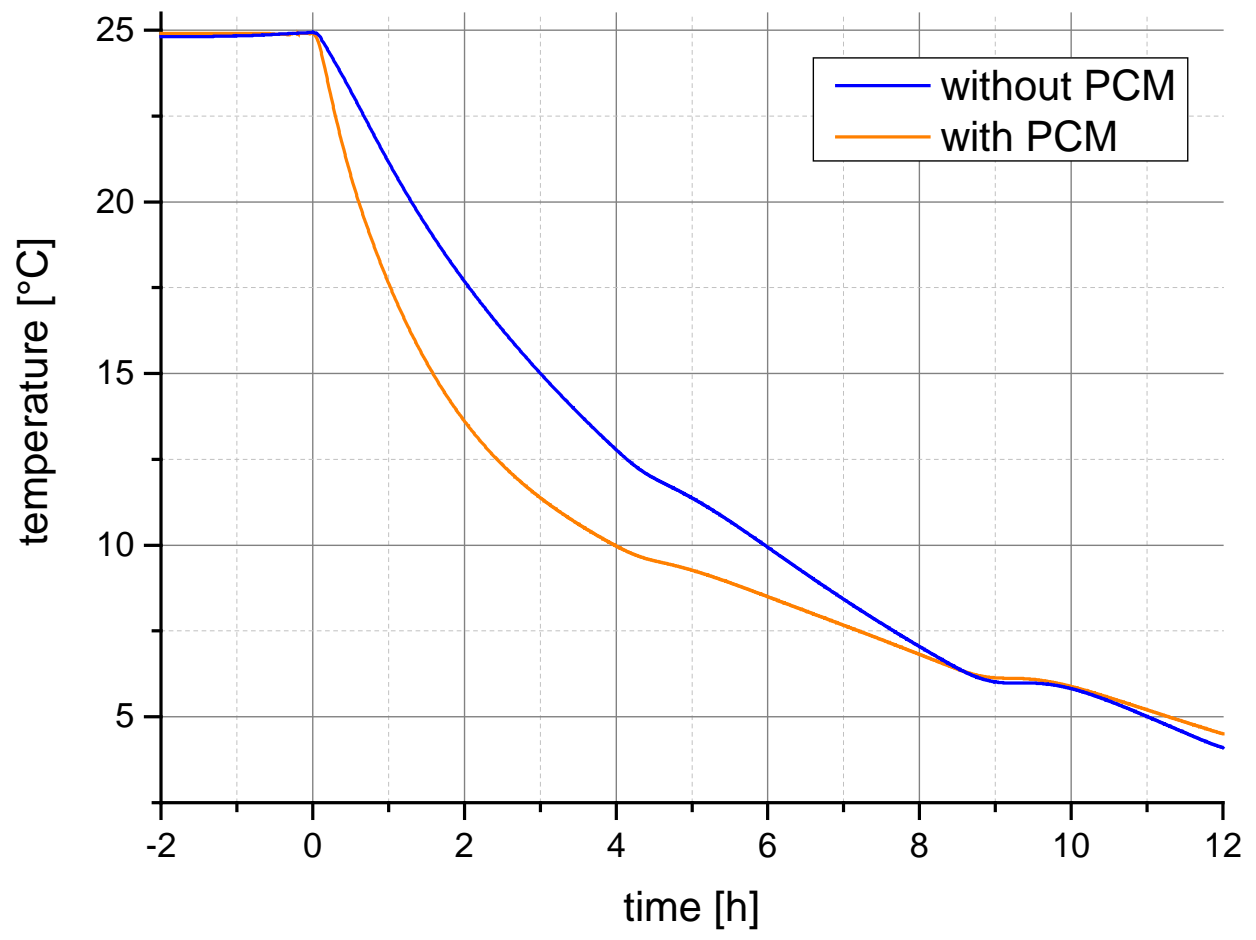

Fig. 6 Mean temperatures of M-packages $\left(T_{M, a}\right)$ during cooling capacity test of refrigerating appliance $\mathrm{C} 1$ without (blue) and with PCM (orange). 


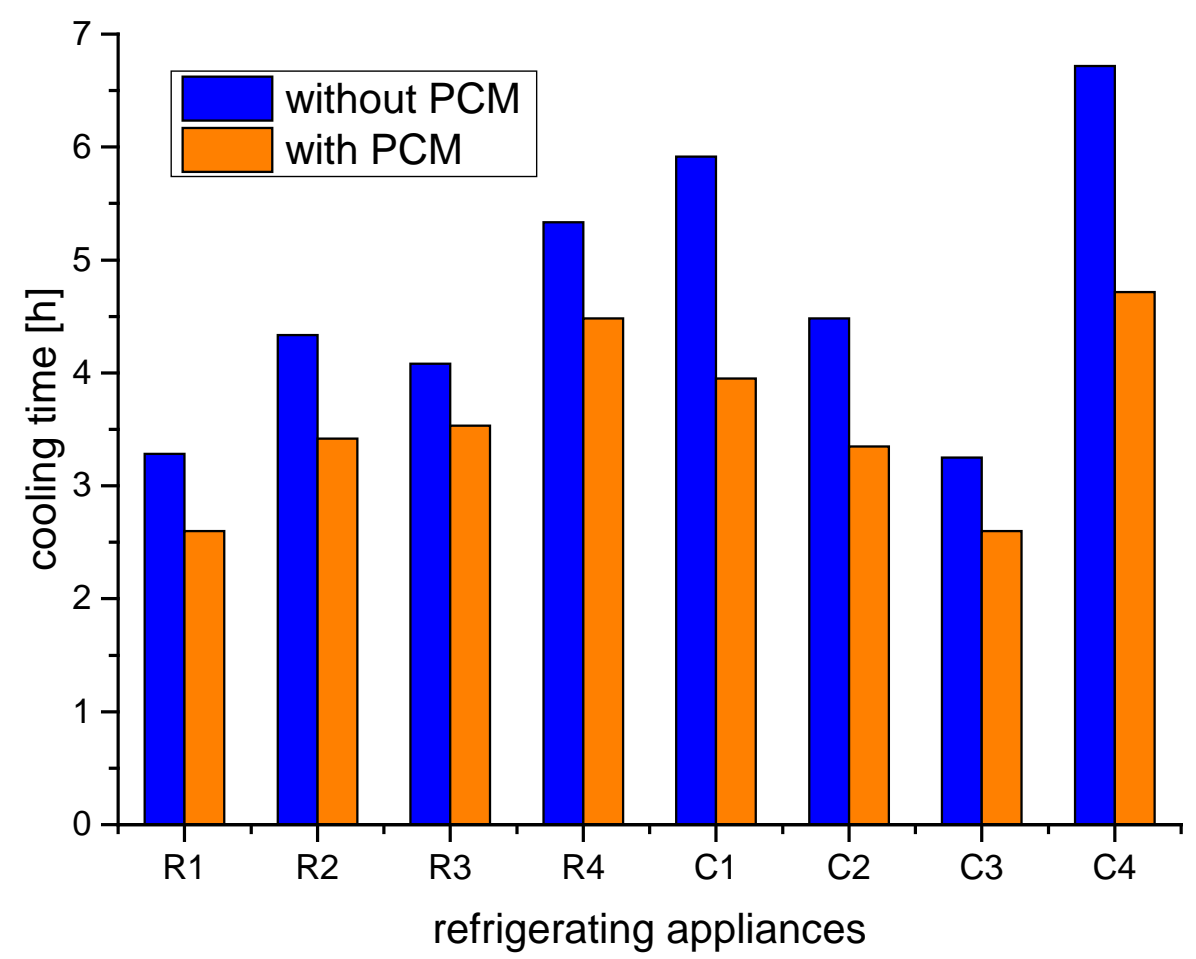

Fig. 7 Cooling capacity test of the studied refrigerating appliances without (blue) and with PCM (orange).

\subsection{Temperature rise}

The temperature rise time in case of (external) switch off, only tested on freezers so far, will in the future be a decisive factor in the context of the use of refrigerators as "smart appliances" for energy peak shaving. Although network connectivity of household refrigerators/freezers is currently not a commercial reality, due to their large number, they might play a role here in the future. The European Commission is currently engaged in a "horizontal preparatory study" on this subject (LOT 33, 2019). The actual temperature rise test in the IEC standard (IEC 62662:2015, Part 2, Annex $\mathrm{C}$ ) determines the time taken for the temperature of a specific load in the freezer compartment to rise from $-18{ }^{\circ} \mathrm{C}$ to $-9^{\circ} \mathrm{C}$ after power is disconnected. Analogously, in this study the temperature rise time was determined in which a specific load in the refrigerator compartment rises from $X{ }^{\circ} \mathrm{C}$ to $\mathrm{Y}^{\circ} \mathrm{C}$.

While the $-18^{\circ} \mathrm{C}$ is clearly defined as the maximum permissible temperature in the compartment of a three- or four-star freezer (IEC 62552:2015, Part 2, Table 2), i.e. the lower temperature limit $\left(\mathrm{X}^{\circ} \mathrm{C}\right)$ can be defined analogously as the maximum permissible temperature of $8^{\circ} \mathrm{C}$ in the fresh-food compartment. The upper temperature limit of $-9^{\circ} \mathrm{C}$ stated in the original freezer test is more or less arbitrary, i.e. not defined 
anywhere else (two-star freezer $<-12{ }^{\circ} \mathrm{C}$, one-star freezer $<-6{ }^{\circ} \mathrm{C}$ ). The only remaining definition is that during a defrost period, which is comparable to a switch off, the temperature may rise by a maximum of $3 \mathrm{~K}$. Following this analogy, the upper temperature limit $\mathrm{Y}{ }^{\circ} \mathrm{C}$ for determining the temperature rise time in fresh food compartments was set to $11^{\circ} \mathrm{C}$ here. Like in section 3.1, the refrigerating appliances were loaded with $4.5 \mathrm{~kg}$ test and M-packages per $100 \mathrm{I}$ (fresh-food compartment) volume according to the filling plan. In analogy to the freezer temperature rise test, the power supply was switched off once stable operating conditions were achieved, and the temperature rise time was determined as the the time during which the arithmetic mean of the temperatures of all M-packages $T_{M, a}$ rises from $8^{\circ} \mathrm{C}$ to $11^{\circ} \mathrm{C}$.

Fig. 8 shows exemplary temperature curves of the M-packages of such a measurement. The influence of the latent heat storage elements integrated into the fresh-food compartment on the temperature rise time is exemplarily shown in Fig. 9. While the temperature of the warmest M-package without PCM rises continuously, the temperature curve with PCM shows a clear temperature plateau in the range of the melting temperature. Thereby, the temperature rise time of refrigerator R1 equipped with PCM was increased by $145 \%$ from 2.2 to $5.4 \mathrm{~h}$. It is also evident that when considering an upper temperature limit of $T_{M, a}=12{ }^{\circ} \mathrm{C}$ instead of $T_{M, a}=11^{\circ} \mathrm{C}$, the increase would even be greater.

Fig. 10 summarizes the results of all temperature rise time measurements. The temperature rise time could be significantly increased by the PCM for all refrigerating appliances, i.e. between 2.15 to $4.48 \mathrm{~h}$ in absolute terms and between 75 to $145 \%$ in relative terms. 


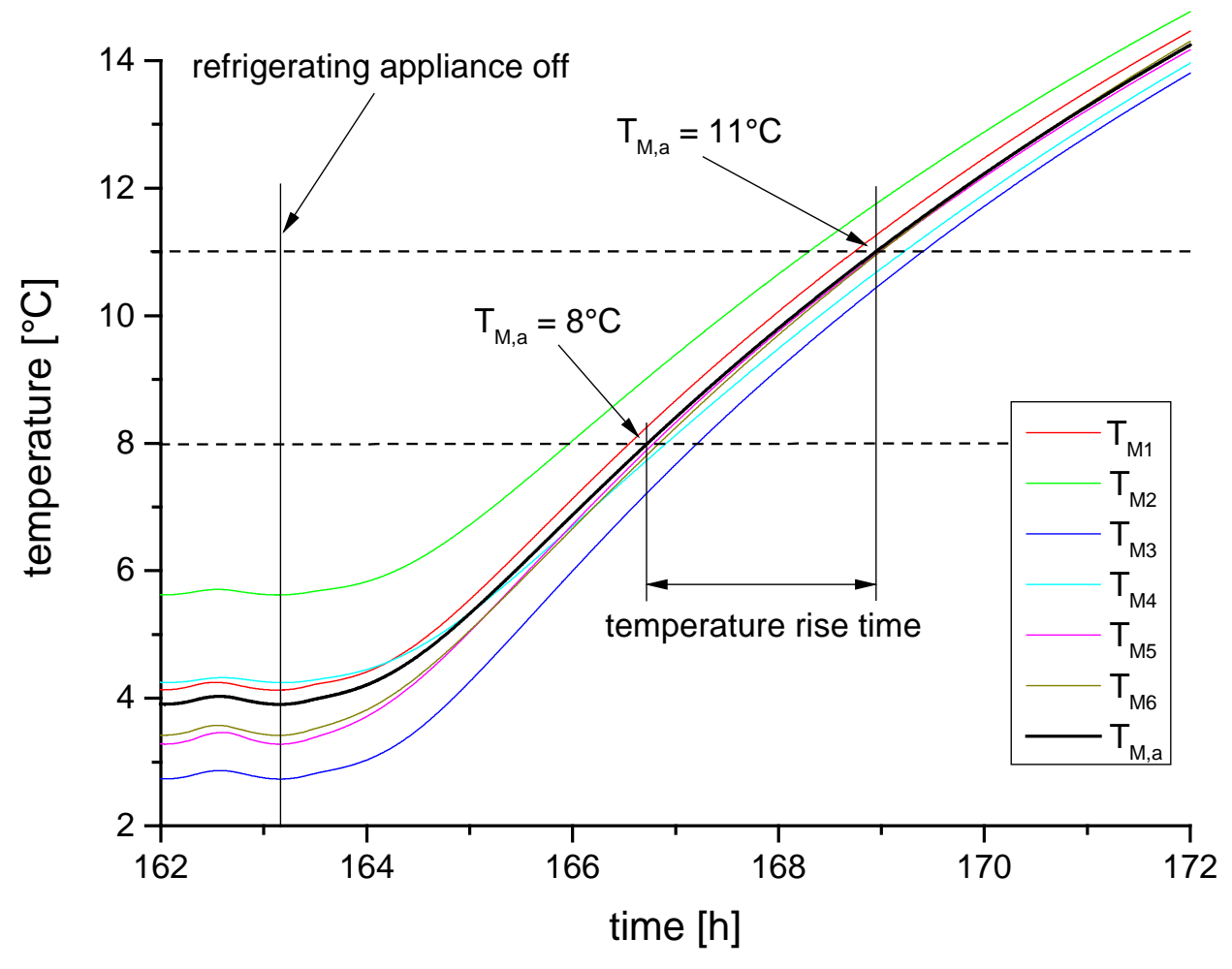

Fig. 8 Temperatures of the M-packages during the temperature rise time test in analogy to IEC 62552:2015. 


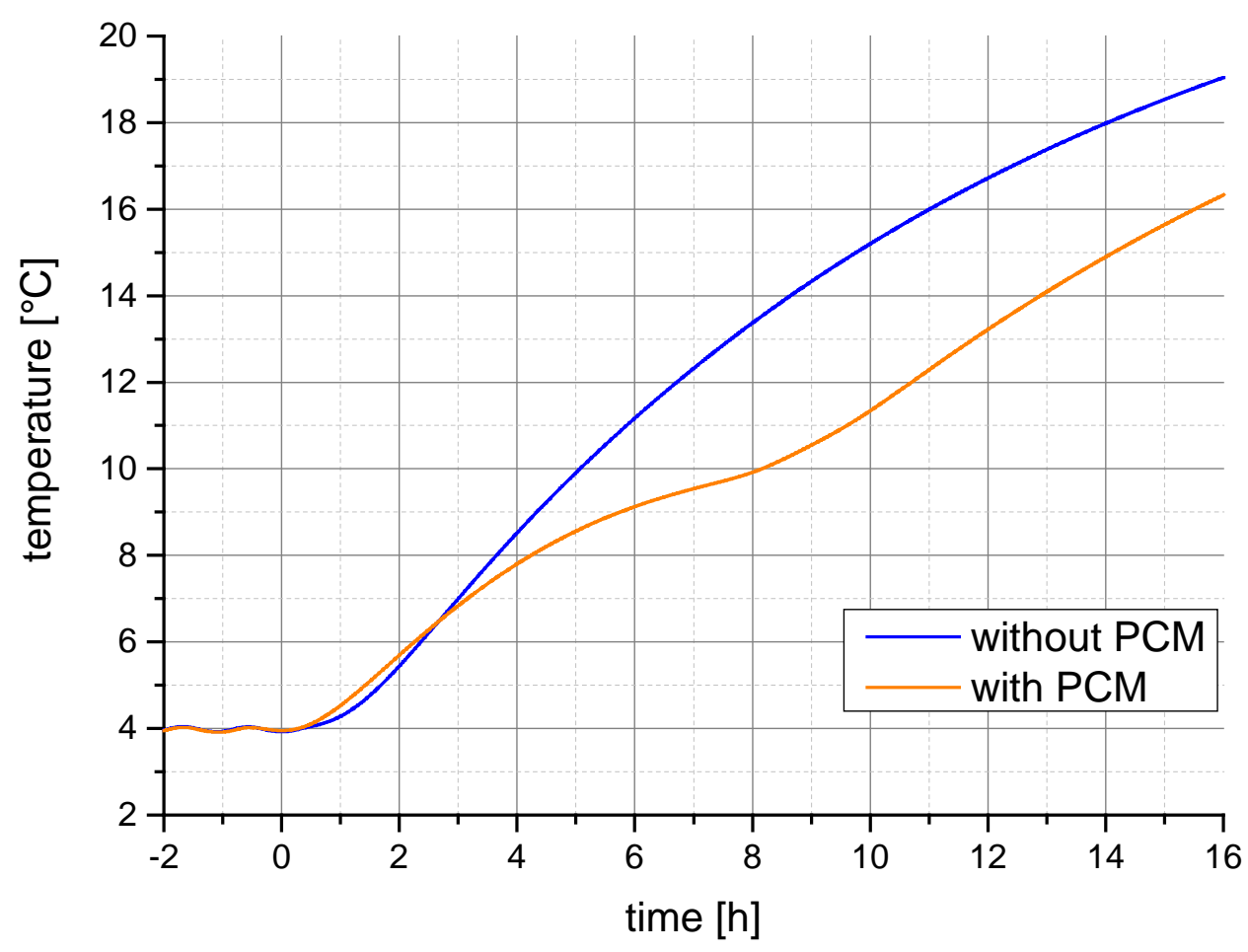

Fig. 9 Mean temperatures of M-packages $\left(T_{M, a}\right)$ during the temperature rise time test of refrigerating appliance R1 without (blue) and with PCM (orange).

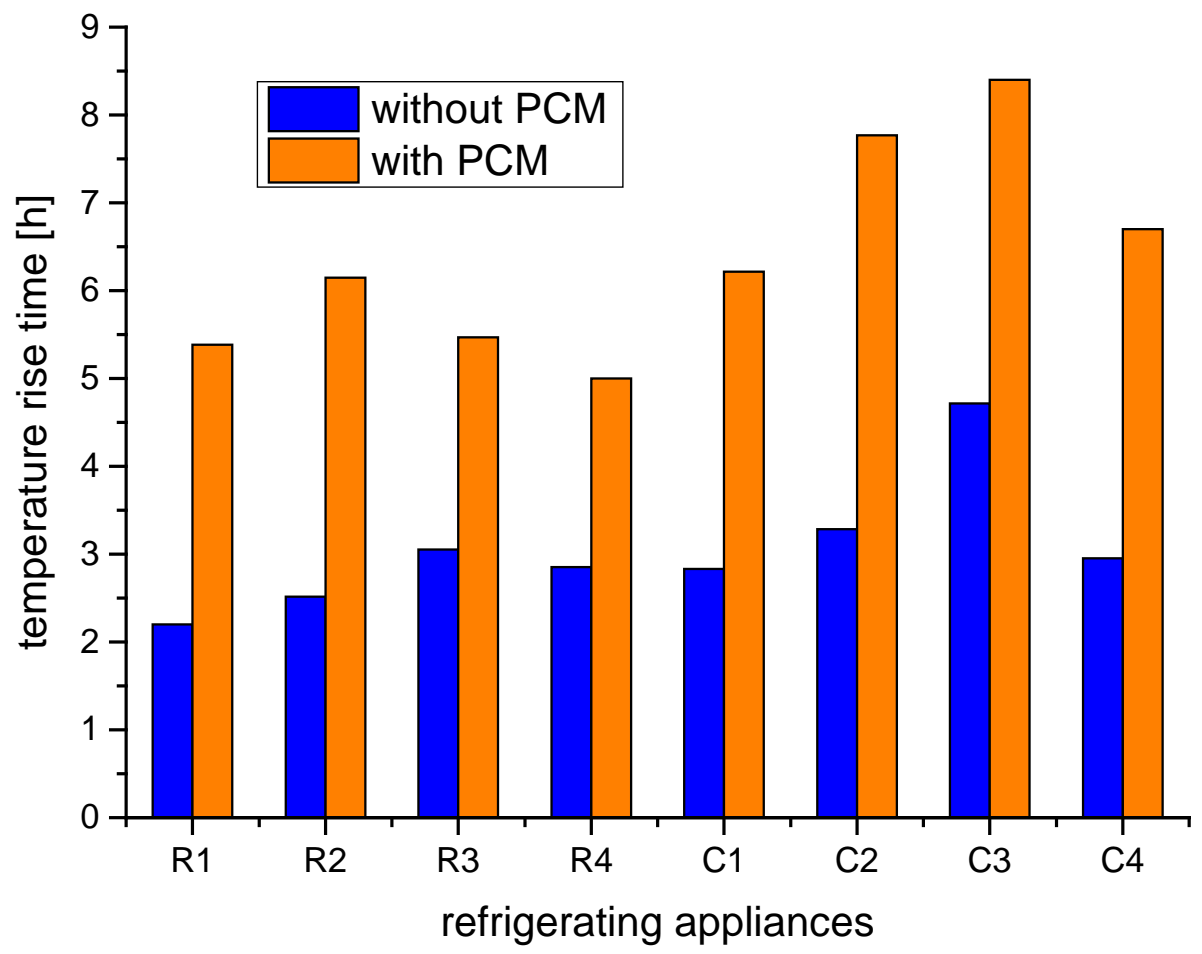

Fig. 10 Temperature rise time of the studied refrigerating appliances without (blue) and with PCM (orange). 


\subsection{Energy consumption}

Even though performance tests have now been internationally standardized with the global standard IEC 62552:2015, the daily energy consumption remains the most important technical specification of a refrigerating appliance. Therefore, the effects of all modifications on power consumption were measured to facilitate their later implementation into practice. A summary of the results including the energy consumption measurements obtained during the experiments of this study is given in Tables 4 and 5. In all cases with PCM, the results show that the cooling capacity as well as temperature rise time was increased without affecting energy consumption. The maximum deviations found here are all within the range of the uncertainty of the energy consumption measurement.

\section{Table 4 - Test results of the studied refrigerators.}

\begin{tabular}{|c|c|c|c|c|c|c|}
\hline \multicolumn{3}{|l|}{ Test device } & $\frac{\mathrm{R} 1}{\text { refrigerator }}$ & $\begin{array}{c}\mathrm{R} 2 \\
\text { refrigerator }\end{array}$ & $\begin{array}{c}\text { R3 } \\
\text { refrigerator }\end{array}$ & $\begin{array}{c}\mathrm{R} 4 \\
\text { refrigerator }\end{array}$ \\
\hline \multicolumn{2}{|c|}{ Fridge storage volume } & {$[1]$} & 158 & 167 & 320 & 216 \\
\hline \multicolumn{3}{|c|}{ Thermostat set point } & $3^{\circ} \mathrm{C}$ & $4^{\circ} \mathrm{C}$ & $3^{\circ} \mathrm{C}$ & $4^{\circ} \mathrm{C} / \mathrm{b} 5$ \\
\hline \multirow{2}{*}{\multicolumn{2}{|c|}{ PCM mass }} & [g] & 2235 & 2271 & 2297 & 2360 \\
\hline & & [kg/100l] & 1.41 & 1.36 & 0.72 & 1.09 \\
\hline \multirow{4}{*}{ Cooling time } & without PCM & [h] & 3.28 & 4.33 & 4.08 & 5.33 \\
\hline & with PCM & [h] & 2.60 & 3.42 & 3.53 & 4.48 \\
\hline & difference & [h] & -0.68 & -0.92 & -0.55 & -0.85 \\
\hline & relative & & $126 \%$ & $127 \%$ & $116 \%$ & $119 \%$ \\
\hline \multirow{4}{*}{$\begin{array}{l}\text { Temperature } \\
\text { rise time } \\
\text { (average) }\end{array}$} & without PCM & [h] & 2.20 & 2.52 & 3.05 & 2.85 \\
\hline & with PCM & [h] & 5.38 & 6.15 & 5.47 & 5.00 \\
\hline & difference & [h] & 3.18 & 3.63 & 2.42 & 2.15 \\
\hline & relative & & $245 \%$ & $244 \%$ & $179 \%$ & $175 \%$ \\
\hline \multirow{2}{*}{$\begin{array}{l}\text { Daily energy } \\
\text { consumption }\end{array}$} & without PCM & [kWh/day] & 0.377 & 0.437 & 0.384 & 0.375 \\
\hline & with PCM & [kWh/day] & 0.371 & 0.431 & 0.384 & 0.379 \\
\hline
\end{tabular}




\begin{tabular}{|c|c|c|c|c|c|c|}
\hline \multirow{2}{*}{\multicolumn{3}{|c|}{ Test device }} & $\mathrm{C} 1$ & $\mathrm{C} 2$ & $\mathrm{C} 3$ & $\mathrm{C} 4$ \\
\hline & & & combination & combination & combination & combination \\
\hline \multicolumn{2}{|c|}{ Fridge storage volume } & {$[1]$} & 232 & 199 & 247 & 185 \\
\hline \multicolumn{2}{|c|}{ Thermostat set point } & & $1^{\circ} \mathrm{C}$ & 5 & $4{ }^{\circ} \mathrm{C} /-16{ }^{\circ} \mathrm{C}$ & 3.6 \\
\hline \multirow{2}{*}{\multicolumn{2}{|c|}{ PCM mass }} & [g] & 2963 & 2814 & 2235 & 1791 \\
\hline & & [kg/100l] & 1.28 & 1.41 & 0.90 & 0.97 \\
\hline \multirow{4}{*}{ Cooling time } & without PCM & [h] & 5.92 & 4.48 & 3.25 & 6.72 \\
\hline & with PCM & [h] & 3.95 & 3.35 & 2.60 & 4.72 \\
\hline & difference & [h] & -1.97 & -1.13 & -0.65 & -2.00 \\
\hline & relative & & $150 \%$ & $134 \%$ & $125 \%$ & $142 \%$ \\
\hline \multirow{4}{*}{$\begin{array}{l}\text { Temperature } \\
\text { rise time } \\
\text { (average) }\end{array}$} & without PCM & [h] & 2.83 & 3.28 & 4.72 & 2.95 \\
\hline & with PCM & [h] & 6.22 & 7.77 & 8.40 & 6.70 \\
\hline & difference & [h] & 3.38 & 4.48 & 3.68 & 3.75 \\
\hline & relative & & $219 \%$ & $237 \%$ & $178 \%$ & $227 \%$ \\
\hline \multirow{2}{*}{$\begin{array}{l}\text { Daily energy } \\
\text { consumption }\end{array}$} & without PCM & [kWh/day] & 1.146 & 0.716 & 0.479 & 0.426 \\
\hline & with PCM & [kWh/day] & 1.164 & 0.710 & 0.475 & 0.423 \\
\hline
\end{tabular}

\section{Conclusions}

A polymer-bound PCM with a phase change temperature around $9{ }^{\circ} \mathrm{C}$ was developed and integrated into the fresh-food compartment of different commercially available household refrigerating appliances. In this experimental study, their influence on daily energy consumption, cooling capacity and temperature rise time according to the global standard IEC 62552:2015 was studied.

The results show a considerable positive influence on the performance indicators cooling capacity and temperature rise, without negatively impacting energy consumption. Through the integration of PCM into the appliances, the cooling capacity was increased by up to $33 \%$ and temperature rise time even by up to $145 \%$.

Given that the present polymer compound is leak proof and (milky) transparent, a direct integration into the fresh-food compartment shelves of household refrigerators/freezers can also be easily implemented into practice. It was shown that this also enhances the suitability of refrigerators/freezers as "smart appliances" to meet the growing demand for balancing energy to compensate the growing volatility of renewable energy.

Nevertheless, future work on developing polymer-bound PCM with lower phase change temperatures and evaluating their effects on cooling capacity and temperature rise time has to be done.

\section{Acknowledgements}

This work was supported by Deutsche Bundesstiftung Umwelt (DBU, AZ 28626). 


\section{References}

Azzouz, K., Leducq, D., Gobin, D., 2008. Performance enhancement of a household refrigerator by addition of latent heat storage. Int. J. Refrig. 31, 892-901.

Azzouz, K., Leducq, D., Gobin, D., 2009. Enhancing the performance of household refrigerators with latent heat storage: an experimental investigation. Int. J. Refrig. 32, 1634-1644.

AHAM HRF-1-2008, 2008. Association of Home Appliance Manufacturers, Energy and Internal Volume of Refrigerating Appliances.

ANSI/AHAM HRF-1-2007, 2007. American National Standard, Energy, Performance and Capacity of Household Refrigerators, Refrigerator-Freezers and Freezers.

AS/NZS 4474.1:2007, 2007. Australian/New Zealand Standard, Performance of household electrical appliances - Refrigerating appliances; Part 1: Energy consumption and performance.

Bansal, P. K.; Krueger, R., 1995. Test standards for household refrigerators and freezers I: preliminary comparison. In: Int. J. Refrig.18 (1), S. 4-20.

Barthel, C., Götz, T., 2012. The overall worldwide saving potential from domes- tic refrigerators and freezers. Wuppertal (Germany). http://www.bigee.net/ media/filer public/2012/12/04/bigee _ doc _ ${ }^{2}$ _ refrigerators _ freezers _ worldwide _ potential _ 20121130.pdf.

R. Ben-Abdallah, D. Leducq, H.M. Hoang et al., Experimental investigation of the use of PCM in an open display cabinet for energy management purposes. Energy Conv. Manag., 2019, 198.

Berdja, M., Hamid, A., Sari, O., 2019. Characteristics and thickness effect of phase change material and frost on heat transfer and thermal performance of conven- tional refrigerator: theoretical and experimental investigation. Int. J. Refrig. 97, 108-123.

Bista, S., Hosseini, S.E., Owens, E., Phillips, G., 2018. Performance improvement and energy consumption reduction in refrigeration systems using phase change material (PCM). Appl. Therm. Eng. 142, 723-735. 
Cheralathan, M., Velraj, R., Renganarayanan, S., 2007. Performance analysis on industrial refrigeration system integrated with encapsulated PCM-base cool thermal energy storage system. Int. J. Energy Res. 31, 1398-1413.

Cofré-Toledo, J., Vasco, D.A., Isaza-Roldán, C.A., Tangarife, J.A., 2018. Evaluation of an integrated household refrigerator evaporator with two eutectic phase-change materials. Int. J. Refrig. 93, 29-37.

Coulomb, D., Dupon, J.L., Pichard, A., 2015. The role of refrigeration in the global economy. http://www.iifiir.org/clientBookline/service/reference.asp?INSTANCE= exploitation\&OUTPUT=PORTAL\&DOCID=IFD _ REFDOC _ 0016453\&DOCBASE= IFD _ REFDOC _ EN\&SETLANGUAGE=EN.

EN 62552:2013, 2013. Household Refrigerating Appliances -Characteristics and Test Methods. European Committee for Electrotechnical Standardization (CENELEC).

European Commission, 2019. Ecodesign Preparatory Study on Smart Appliances (Lot 33). https://eco-smartappliances.eu/en

Faberi, S., Esposito, R., Mebane, W., Presutto, M., Sciadoni, R., Stamminger, R., 2007. Preparatory Studies for Eco-design Requirements of EuPs: Final Report Domestic Refrigerators \& Freezers. TREN/D1/40-2005.

Gin, B., Farid, M.M., 2010. The use of PCM panels to improve storage condition of frozen food. J. Food Eng. 100, 372-376.

Gin, B., Farid, M.M., Bansal, P.K., 2010. Effect of door opening and defrost cycle on a freezer with phase change panels. Energy Convers. Manag. 51, 2698-2706.

IEC 62552:2015, 2015. IEC 62552:2015 Household Refrigerating Appliances -Characteristics and Test Methods. International Electrotechnical Commission (IEC).

JIS C 9801:2006, 2006. Japanese Industrial Standard, Household refrigerating appliances - Characteristics and test methods.

Khan, I., Afroz, H., 2015. Effect of phase change material on compressor on-off cycling of a household refrigerator. Science and Technology for the Built Environment, 21:4, 462-468. 
Liu, Z., Zhao, D., Wang, Q., Chi, Y., Zhang, L., 2017. Performance study on air-cooled household refrigerator with cold storage phase change materials. Int. J. Refrig. 79, 130-142.

Lu, W., Tassou, S.A., 2013. Characterization and experimental investigation of phase change materials for chilled food refrigerated cabinet applications. Appl. Energy 112, 1376-1382.

Maiorino, A.; Duca, M.G.; Mota-Babiloni, A.; Greco, A.; Aprea, C. The thermal performances of a refrigerator incorporating a phase change material. Int. J. Refrig. 2019, 100, 255-264.

Mastani Joybari, M., Haghighat, F., Moffat, J., Sra, P., 2015. Heat and cold storage using phase change materials in domestic refrigeration systems: the state-of- the-art review. Energy Build 106, 111-124.

Mehling, H., Cabeza, L.F., 2008. Heat and Cold Storage with PCM. An up to Date Introduction into Basics and Applications. Springer-Verlag, Berlin, Heidelberg.

Onyejekwe, D., 1989. Cold storage using eutectic mixture of $\mathrm{NaCl} / \mathrm{H} 2 \mathrm{O}$ : an application to photovoltaic compressor vapours freezers. Sol. Wind Tech. 6, 11-18.

Oró, E., Miró, L., Farid, M.M., Cabeza, L.F., 2012a. Improving thermal performance of freezers using phase change materials. Int. J. Refrig. 35, 984-991.

Oró, E., Miró, L., Farid, M.M., Cabeza, L.F., 2012b. Thermal analysis of a low temperature storage unit using phase change materials without refrigeration system. Int. J. Refrig. 35, 1709-1714.

Sonnenrein, G., Elsner, A.. Baumhögger, E., Morbach, A., Fieback, K., Vrabec, J., 2015. Reducing the power consumption of household refrigerators through the integration of latent heat storage elements in wire-and-tube condensers. Int. J. Refrig. $51,154-160$.

Sonnenrein, G., Baumhögger, E., Elsner, A., Fieback, K., Morbach, A., Paul, A., Vrabec, J., 2015. Copolymer-bound phase change materials for household refrigerating appliances: experimental investigation of power consumption, tem- perature distribution and demand side management potential. Int. J. Refrig. 60, 166-173. 
Visek, M., Joppolo, C.M., Molinaroli, L., Olivai, A., 2014. Advanced sequential dual evaporator domestic refrigerator/freezer: System energy optimization. Int. J. Refrig. 43, 71-79.

Wang, F., Maidment, G., Missenden, J., Tozer, R., 2007a. The novel use of phase change materials in refrigeration plant. Part 1: experimental investigation. Appl. Therm. Eng. 27, 2893-2901.

Wang, F., Maidment, G., Missenden, J., Tozer, R., 2007b. The novel use of phase change materials in refrigeration plant. Part 2: dynamic simulation model for the combined system. Appl. Therm. Eng. 27, 2902-2910.

Wang, F., Maidment, G., Missenden, J., Tozer, R., 2007c. The novel use of phase change materials in refrigeration plant. Part 3: PCM for control and energy savings. Appl. Therm. Eng. 27, 2911-2918.

Yusufoglu, Y., Apaydin, T., Yilmaz, S., Paksoy, H.O., 2015. Improving performance of household refrigerators by incorporating phase change materials. Int. J. Refrig. 57, 173-185. 